\title{
Bilişsel Uyumsuzluk Teorisi Üzerine Kavramsal Bir İnceleme: Satın Alma Perspektifi ${ }^{1}$
}

\section{Conceptual Analysis on the Theory of Cognitive Dissonance: Purchasing Perspective}

Esin YÜCEL, Akdeniz Üniversitesi, Türkiye, esinyucel@akdeniz.edu.tr Beykan ÇİZEL, Akdeniz Üniversitesi, Türkiye, beykan@akdeniz.edu.tr

Öz: Bilişsel uyumsuzluk karar verme eylemi sonrasinda yaşanabilen, psikolojik olarak rahatsı edici bir durumdur. Bireylerin tüm eylem ve davranışları, bilinçli ya da bilinçsiz olarak bir karar verme işlemidir. Karar verme davranışı, yașamin her așamasında kendini gösterir ve karar vermenin söz konusu olduğu her durumda bilişsel uyumsuzluk yaşama olasıllğ̆ vardır. Leon Festinger, 1957 yllinda bireyin inandiğı sey ile bu inanca karsı çıkan bilginin tutarsızlı̆̆ nedeniyle ortaya çıkan ve psikolojik olarak rahatsı edici bir durum olan "Bilișsel Uyumsuzluk" teorisini tanımlamıştır. Sosyal psikolog Leon Festinger'in bilişsel uyumsuzluk teorisi, sosyal psikoloji tarihinde en önemli ve etkili teorilerden biri olarak görülmektedir. Satın alma davranışı da alternatifler arasından seçim yaparak karar vermeyi gerektirir ve bu nedenle teori, tüketici davranıșlarının nedenlerini anlamaya çalıșan pazarlama teorisyenleri tarafindan da benimsenmiștir. Buna göre çalı̧̧manın amacı, teorinin ortaya çıkışını ve temel kavramlarını tanımlayarak teorinin anlaşılmasını sağlamak, satın alma ve tüketici davranışı alanında teorik ve ampirik araştırmaların yolunu açmaktır. Bilimsel araștırmalara yönelik mevcut boşlukların tanımlanmasının konuya olan ilgiyi artırma ve bilginin geliştirilerek daha fazla kullanılması yoluyla genelleştirilebilirliğini artırma çabalarına katkda bulunduğu düşünülmektedir.

Anahtar Sözcükler: Bilişsel Uyumsuzluk, Çelişsi, Tüketici Davranışı, Satın Alma Davranışı

Abstract: Cognitive dissonance is a psychologically disturbing condition that can be experienced after a decision-making process. Every actions and behaviors of individuals is a decision making process, consciously or unconsciously. Decision-making behavior manifests itself at every stage of life and there is the possibility of cognitive dissonance in any situation where the decision-maker is concerned. Leon Festinger described the theory of "Cognitive Dissonance", as a psychologically disturbing phenomenon that emerged in 1957 due to the inconsistency of this belief in what the individual believes. Social psychologist Leon Festinger's theory of cognitive dissonance is seen as one of the most important and effective theories in the history of social psychology. Purchasing behavior also requires decision making by choosing among alternatives, and therefore the theory is also adopted by marketing theorists who understand the causes of consumer behavior. Accordingly, the aim of the study is to explain the theory and the basic concepts of the emergence of the theory, to provide the understanding of the theory, the theoretical and empirical investigations in the field of purchasing and consumer behavior. It is believed that the identification of existing gaps for scientific research contributes to efforts to augment the generalizability of the issue through further enhancement and further use of knowledge.

Keywords: Cognitive Dissonance, Contradiction, Consumer Behavior, Decision Making Behavior

\section{Giriş}

Bilişsel uyumsuzluk teorisi, bireyin uyumlu ve tutarlı zihin yapısına ulaşma amacını ele alan tutarlılık kuramlarının bir parçası olarak görülebilir. Bilişsel sistemdeki tutarsızlıklardan kaynaklanan motivasyonel sonuçların kabul edildiği ve tanımlandığı ilk teoridir (Breker, 2009: 5). 1960'larda sosyal psikolojinin en fazla araştırılan konusu olan bilişsel uyumsuzluk, kişinin birbiriyle tutarsız iki ya da daha fazla biliş’e (bilgi parçaları) sahip olması sonucu ortaya çıkan psikolojik rahatsızlık durumudur. Uyumsuzluğa neden olan tutarsız düşüncelere sahip olunduğunda duygularla yüzleşmek olarak da tanımlanabilir. Bu uyumsuzluk tatsızdır ve birey farklı bakış açısı sunan bilgi kaynaklarını önlemenin ya da kendi düşüncelerini rasyonalize etmenin yollarını arar (Tanford ve Montgomery, 2015: 4). Bireyler, bir seçim yapmaları gerektiğinde yapılan seçimle uyumsuz olan bilişler rahatsızlık yaratır. Satın alma davranışları da bir seçim yapmayı gerektirdiğinden teori tüketici davranışlarını anlamak için bir bakış açısı sunmaktadır.

Çalışma dört bölümden oluşmaktadır. Giriş bölümünü takip eden ikinci bölümde, bilişsel uyumsuzluk teorisi ayrıntılı olarak ele alınmıştır. Üçüncü bölümde, satın alma aşamalarında bilişsel uyumsuzluk konusu literatür taraması ile birlikte irdelenmiştir. Dördüncü bölümde ise tüm bu bilgiler, satın alma aşamalarında tüketici davranışını anlamak adına sektöre ve araştırmacılara yön verebilecek şekilde yorumlanmıştır.

\footnotetext{
${ }^{1}$ Bu çalışma Prof. Dr. Beykan Çizel danışmanlığında, Esin Yücel tarafindan Akdeniz Üniversitesi Sosyal Bilimler Enstitüsü'nde 2017 yllında tamamlanan Doktora Tezinden üretilmişsir.
} 


\section{Bilişsel Uyumsuzluk}

\subsection{Tanımı ve Kapsamı}

17. yy'da Osmanlı topraklarında (İzmir) doğan ve mesihlik iddiasında bulunan Sabetay Sevi'nin kehanetleri ve müritlerinin gerçekleşmeyen kehanetler karşısında korudukları inançlarından başlayarak çarpıcı örneklerle teorinin temellerini atan Leon Festinger ve meslektaşları, tarihteki örneklerinden yola çıkarak, 1955'te Clarion adlı bir gezegendeki üstün varlıklar tarafından kendisine mesajlar gönderildiğini iddia eden Marian Keech'in, 21 Aralık’ta yeryüzünün büyük bir selle yok olacağı ve inananların üstün varlıklar tarafindan kurtarılacağ1 yönündeki kehanetlerini ve gerçekleşmemesi durumunda kişilerin tepkilerini, mürit rolünde girdikleri tarikatta gözlemlemişlerdir. "Arayanlar (Seekers)" olarak adlandırılan tarikat üyelerinin gerçekleşmeyen kehanetler karşısında nasıl tepki verdiklerini tespit etmeye çalıştıkları araştırmada, bazı üyelerin kehanet gerçekleşmediğinde kendilerini aptal gibi hissettiklerini belirtmelerine karşın çoğunluğu oluşturan daha kararlı üyeler, yaptıklarını ve inançlarını haklı çıkarmaya çalışmışlardır (Festinger vd., 1956: 11, 30, 31). Kararlı üyelere göre olayın gerçekleşmemesi kendilerine verilen ikinci bir şanstır ve bu zamanda tarikata daha fazla taraftar toplamalı, daha fazla insanı kurtarmak için çaba sarf etmelidirler. Araştırmacılar, tarikat üyelerinin bu gibi savunmalarla inançlarını haklı çıarma çabalarını heyecan verici olarak karşılamışlar ve uyumsuzluk teorisinin yakın zamanda Leon Festinger tarafından yazılacak olan kitapta detaylandırılacağını belirtmişlerdir (Festinger vd., 1956: 251). Sonrasında, Leon Festinger (1957) bireyin inandığ 1 şey ile bu inanca karşı çıkan bilginin tutarsızlığ nedeniyle ortaya çıkan ve psikolojik olarak rahatsız edici bir durum olan "Bilişsel Uyumsuzluk" teorisini tanımlamıştır.

Sosyal psikolog Leon Festinger'in (1957) bilişsel uyumsuzluk teorisi, sosyal psikoloji tarihinde en önemli ve etkili teorilerden biri olarak görülmektedir. Kendisi de kıdemli bir psikolog olan Aronson (1997: 128), teoriyi "psikolojide şimdiye kadar okuduğum en heyecan verici teori, 40 y1l sonra tekrar okudum ve yine psikolojide şimdiye kadar okuduğum en heyecan verici teori" şeklinde yorumlamıştır. Biliş ve teşvik ettiği motivasyon arasındaki bağlantı, insanların tutum ve davranışları arasındaki ilişkiler üzerine getirdiği değişimle alana katkılar yapan teori, geniş bir uygulanabilirliğe sahiptir ve tüketici davranışı da dâhil olmak üzere birçok disiplinde önem taşımaktadır (Bawa ve Kansal, 2008: 33).

Festinger (1957: 2), teorisini açıklarken bilişler arasındaki tutarlılık (consistency) için daha tarafsız olduğunu düşündüğü uyum (consonance) terimini ve tutarsızlık (inconsistency) için daha az mantıksal ça ğrışıma sahip olduğunu düşündüğü uyumsuzluk (dissonance) terimini kullanır. Uyumsuzluk ve uyum terimleri, unsur/eleman/öge çiftleri arasında var olan ilişkileri ifade eder. Bu unsurlar, kişinin kendisi, davranışları ve çevresi hakkında bildiği şeyleri ifade eden bilişler yani "bilgi"lerdir. Bu ögelerden bazıları, bireyin yapmak istedikleri ve hissettikleridir. Diğer bilgi unsurları ise bireyin yaşadığı dünyayla ilgilidir. Örneğin hangi olay neye yol açar, ne tatminkâr ya da acı vericidir, önemsiz veya önemlidir gibi. Festinger'e göre, görüşler de bilgidir. Çünkü birey doğru olduğunu düşünmediği sürece görüşte bulunmaz ve dolayısıyla psikolojik olarak görüş, bilgiden farklı değildir. Aynı şey "bilgi" olarak işlev gören inançlar, değerler veya tutumlar için de geçerlidir. Hepsi "biliş unsurları"dır ve uyum ve uyumsuzluk ilişkileri bu unsur çiftleri arasında olur. Diğger bir ifadeyle biliş unsurları, çoğunlukla kişinin gerçekte ne yaptığına veya hissettiğine ya da aslında çevrede ne olduğuna karşılık gelir. Buradaki önemli fark "gerçeklik"tir. Görüşler, inançlar ve değerler söz konusu olduğunda gerçeklik, başkalarının düşünceleri veya yaptıkları olabilir; bir başka durumda gerçeklik, deneyimlenen durum ya da başkalarının bireye ifade ettikleri olabilir. Sonuç olarak önemli husus bir kişiyi etkileyen gerçekliğin, ilgili bilişsel unsurları gerçeğe uygun hale getirme yönünde bireye baskı uygulayacağıdır. $\mathrm{Bu}$, bilişsel unsurlar belirli bir gerçekle uyuşmuyorsa belirli baskının var olması gerektiği anlamına gelir. Uyumsuzluk teorisinin önemli sonuçlarından biri, bilişsel unsurların gerçekle örtüşmediği bazı koşulları anlamamıza yardımcı olmasıdır (Festinger, 1957: 9-11).

Festinger (1957: 39) ayrıca "çatışma (conflict)" teriminin yanlış kullanıldığını, çatışma ve uyumsuzluk terimleri arasında önemli bir farkın olduğunu savunur. Kavramların uygun kullanımları karar öncesi ve sonrası durumlara bağlıdır. Örneğin iki iş teklifi alan bir kişi için, A işinin olumlu özelliklerine ve B işinin istenmeyen özelliklerine sahip bilişsel küme ile B'nin olumlu özelliklerine ve A'nın olumsuzluklarına sahip bilişsel kümeler söz konusudur. Aslında bir şeyi beğenmekle ve başka bir şeyi ayrıca beğenmek arasında bir karşıtlık yoktur. Çatışma, bireyin olası iki şey arasında seçim yapmak zorunda olması durumunda ortaya çıkar. Çünkü kişi her ikisine birden sahip olamaz ve aynı anda iki zıt yönde itilir. Kişi er ya da geç kararını verecek ve herhangi birini seçecektir. Artık iki karşıt yönde itilmez, alternatiflerden birini seçmiştir. Fakat şimdi bilişsel kümelerden biri, hareket ettiği yön ile uyumsuzdur. Bilişsel düzeyde uyumsuzluk vardır. Karar vermeden önce kişi çatışma durumundadır. Kararı verdikten sonra artık çatışma içinde değildir; seçimini yapmış ve çatışmayı çözmüştür. Festinger (1957: 40), "çatışma" teriminin daha sınırlı şekilde kullanılmasını önermiştir.

Türk dilindeki kullanımına bakıldığında "çatışma" aynı anda ortaya çıkan birbirine karşıt ya da eşit derecede çekici dilek ve isteklerin bireyde yarattığı ruhsal durum olarak tanımlanmaktadır (TDK, 2017). Günlük söylemlerde ve literatürde sıklıkla "bilişsel çelişki" olarak ifade edildiği görülmektedir. Çelişki (contradiction) 
söylenen sözlerin birbirini tutmaması, paradoks (düşünceler arasında tartışmaya açık, kesin bir yargı içermeyen karşıtlık) olarak tanımlanır (TDK, 2017). Bu anlamda çatışma ve çelişkinin karar öncesinde yaşanan durumu tanımlaması anlamında Türk literatüründe de "bilişsel uyumsuzluk" olarak kullanılması uygun görünmektedir.

Festinger'e göre birbiriyle alakalı bilişler, uyumlu veya uyumsuz olabilir. Uyum, bir bilişin diğerinden sonra geldiği durumlarda, uyumsuzluk ise bir bilişin diğerinin tersini gerektirmesi durumunda oluşur. Bunu biçimsel olarak bir durum, düşünce ya da olgunun (x) tersi olan tarafı (-x) diğerini (y) takip ediyorsa $\mathrm{x}$ ve $\mathrm{y}$ arasında uyumsuz bir ilişki vardır şeklinde açıklar ve "bir kişi borçluysa ve aynı zamanda yeni bir araba satın aldıysa, bilişsel unsurlar birbiri ile uyumsuz olurdu" örneğini verir. İkinci uyumsuzluk kaynağı ise bir tutum ve bir davranış ya da iki davranış arasındaki tutarsızlıktır (Festinger, 1957: 9, 13).

Festinger'in 1957 yılında formülize ettiği teorisinin 2 temel hipotezi vardır: (1) psikolojik olarak rahatsız edici bir durum olan uyumsuzluğun varlığı, kişiyi uyumsuzlukları azaltmaya ve "uyum"a motive edecektir. Uyumsuzluğun yani bilişler arasındaki tutarsız ilişkilerin varlığı, kendi başına motive edici bir faktördür. Bilişsel uyumsuzluğun azaltılması motivasyonu, açlı̆̆ın açlık azaltmaya yönelik davranışlara yol açtığı gibi uyumsuzluğun azaltılmasına yönelik etkinliğe götüren öncül bir durum olarak görülebilir. (2) uyumsuzluk olduğunda bunu azaltmaya çalışmanın yanı sıra, kişi uyumsuzluğu artıracak durum ve bilgileri aktif olarak önleyecektir (Festinger, 1957: 3).

Festinger'in bilişsel uyumsuzluk teorisi alternatiflerin cazibesinin farklılaşmasına yol açan bilişsel sürecin ancak kararın verilmesinden sonra ortaya çıktığı ve daha önce olmadığını ortaya koymaktadır. Karar sonrası durum, karar öncesi durumdan dinamik olarak farklıdır ancak karar öncesi durumla yakından ilişkilidir. Bir karar verildikten sonra var olan uyumsuzluk miktarı, kişinin bu kararla tutarsız olduğunu bildiği şeylerin doğrudan fonksiyonudur. Karardan önce tutarsızlık ne kadar büyük olursa sonrasında uyumsuzluk o kadar büyük olur. Dolayısıyla, kişi karar vermekte daha fazla zorluk yaşar, daha sonra kararını rasyonalize etme yani uyumsuzluğu azaltma eğilimi artar (Festinger, 1964: 2).

Karar verme öncesinde kişinin alternatifler ile ilgili bilgi toplama ve değerlendirme faaliyetleri tarafsız ve objektiftir. Karar öncesi sürecin "tarafsız" ve "objektif" olması, değerlendirmelerinin bir alternatif lehine önyarg1 içermediğini ifade eder. Kişi, alternatifleri ve bu alternatiflerin muhtemel sonuçlarını belirlemek ve nihai olarak doğru bir karara ulaşmak için bilgi arar. Alternatiflerin çekiciliğinde değişiklikler olabileceği gibi, bunlar sistematik olmayacaktır. Bununla birlikte, karar alındığında ve uyumsuzluk azaltma süreçleri başladıktan sonra, seçilen alternatif lehine çekicilikte artan farklılıklar gözlenir. Deneyler, alternatiflerin cazibesinin farklılaşmasına yol açan bilişsel sürecin ancak kararın verilmesinden sonra ortaya çıktığını ve daha önce olmadığını ortaya koymaktadır (Festinger, 1964: 8).

Bilişsel süreçteki bu değişiklik, karar sonrasında uyumsuzluğu azaltan bilginin aranmasına, artıran bilginin önlenmesine neden olur ve bu seçici olarak maruz kalma (selective exposure) olarak adlandırılır (Festinger, 1957: 137). Karar aldıktan sonra, karara belirli bir derecede bağlı olduğunu hisseden birey için bilgi arama davranışı aldığı son kararı kısmen haklı çıkarmaya hizmet eder ve bu aşamada kararını desteklemeyen bilgiye kıyasla kararlarını destekleyen (uyumlu) bilgiyi tercih eder. Bu taraflı bilgi arayışı benzerlik eğilimi (uyum yanlılı̆̆l) olarak bilinir. Ayrıca Festinger'e göre (1964: 65), bireyler uyumlu bilgileri ortaya çıkarmanın ya da uyumsuz bilgilerden kaçınmanın yanında, istemeden de olsa uyumsuz bilgiye maruz kaldıkları zaman bile bu bilgileri yanlış algılama, bilgilerin geçerliliğini inkâr etme (çürütme/yalanlama) ve benzeri yollarla uyumsuz bilgiden kaçma eğilimindedirler.

Liang (2014: 59) da satın almaya ilişkin araştırmasında, bireylerin bilişsel uyumsuzluk uyandıran bir karar verdikten sonra çevrimiçi yorumları seçerken uyumsuzluk azaltma stratejisi olarak benzerlik eğilimini (uyum yanlılığı) ve çürütme (yalanlama) perspektifini kullandıklarını doğrulamıştır.

Kah ve Lee (2016: 387) seçici maruz kalma paradigmasını sorguladıkları araştırmalarında, bireylerin karar öncesinde alternatifleri değerlendirmek ve bilgi edinmek için uyumsuz bilgi kaynaklarını, karar sonrasında ise kararı teyit etmek için uyumlu bilgi kaynaklarını kullandıklarını ortaya koymuşlardır. Ehrlich ve meslektaşları (1957: 98) seçici maruz kalmayla ilgili araştırmalarında, yeni araç sahiplerinin kendi otomobillerinin reklamlarını, daha önce dikkate aldıkları ancak satın almadıkları ve seçime hiç dâhil olmayan diğer otomobillerin reklamlarından daha sık okuduklarını, bu bulgunun önemli bir kararın ardından kişilerin uyumlu veya destekleyici bilgi aradıkları teorisini desteklediğini belirtmişlerdir. Engel (1963: 58), 1963 yılında Chevrolet reklamlarını, Chevrolet sahibi olanlar ve olmayanlar açısından incelemiştir. Sonuçlar, satın alımlarını destekleyici bilgiler toplama açısından Chevrolet sahibi olan gazete okuyucularının, bu reklamları okuma olasılığının daha fazla olduğunu ortaya çıkarmıştır. Araştırmacılar, kişilerin satın alım sonrasında ürün reklamlarını daha çok okuyor olmasına ilişkin bulguların reklam verenler tarafından ihmal edilmemesi gerektiğini savunmuşlardır. Uyumsuzluk yaşayan bir tüketici memnuniyetsiz bir tüketici haline gelebilir. Daha önce dikkatten kaçan reklamlar fark edilebilir veya alıcı tarafından hatırlanabilir. Satın alınan markaya yönelik reklamlar bu grup için özel avantajlar içermiyor olsalar bile, ilgili marka sahipleri tarafindan fark edilecektir. Ford reklamlarının bir kısmının Ford sahiplerine yönelik olması, son alıcıları bir tanıtım hedefi olarak gören ve satışlardan daha fazla değer elde etmeye çalışan satış politikalarıdır. 
Fakat uyumsuzluk uyarımının bireyin seçici bilgi arayışına etkisi konusunda teoriden gelen tahminleri desteklemeyen çalışmalar (Brownstein, 2003; Koller ve Salzberger, 2007; 2012) ve alternatiflerin cazibesindeki ayrışmanın karar öncesi ve karar sonrası süreçlerde dinamik olarak farklı olmadığını savunan teorik tutumlar da vardır. Bu görüşe göre, kararın mümkün olabilmesi için alternatiflerin cazibesindeki ayrışma (yayılma) karar verme öncesinde başlar. Kararın kendisi devam eden psikolojik süreçleri keskin bir şekilde değiştirmez. Bu, "karar verme eylemi"nin psikolojik süreç açısından hiçbir şekilde kritik öneme sahip olmadığı anlamına gelir. Fakat karar, bilişsel süreçte nitel bir değişiklik başlatır. Deneysel kanıtlar açıkça, kararın önemli bir fark yarattığını ortaya koymaktadır (Festinger, 1964: 97).

Özetle, bilişsel uyumsuzluk karar sonrasında ortaya çıkar. Karar öncesi süreçte tarafsız ve objektif olan bilgi toplama ve değerlendirme davranışının, karar sonrasında yerini benzerlik eğilimi (uyum yanlılığı) ya da çürütme (yalanlama) perspektifine bırakması da bu yüzdendir.

\subsection{Uyumsuzluğun Büyüklü̆̆̈̈̈}

Herhangi iki bilişsel unsur arasında oluşabilecek en büyük uyumsuzluk, en az dirençli elemanın, değişimine karşı toplam direncine eşittir. Uyumsuzluğun büyüklüğü bu miktarı aşamaz çünkü mümkün olan en fazla uyumsuzluğun bu noktasında daha az dirençli unsur değişir, böylece uyumsuzluk ortadan kalkar. Bu, uyumsuzluğun büyüklüğünün sıklıkla mümkün olan bu en yüksek değere yaklaşacağı anlamına gelmez (Festinger, 1957: 28).

Uyumsuzluğun büyüklüğü, azaltılmasına yönelik baskıyı belirlemede önemli bir değişkendir. Uyumsuzluk arttıkça, azaltma baskısı da artar (Harmon-Jones ve Mills, 1999: 4). Kararın önemi ve değeri uyumsuzluk boyutlarını belirleyen en önemli değişkenlerden biridir (Festinger, 1957: 18). Uyum ya da uyumsuzluk bilişsel unsurların önemi veya değeri arttıkça artar. Bilişsel unsurların iki kümesi arasında var olan uyumsuzluk toplamı, uyuşmayan iki küme arasındaki tüm alakalı ilişkilerin ağırlıklı oranının bir fonksiyonudur. "Ağırlıklı oran" terimi kullanılır çünkü her ilişki, o ilişkide bulunan unsurların önemine göre ağırlıklandırılacaktır (Festinger, 1957: 6). Uyumsuzluk miktarı, uyumsuz olan ilgili unsurların oranına bağlıdır. Dolayısıyla, eğer ilgili unsurların ezici çoğunluğu davranışsal unsurla uyumluysa, o zaman bu davranışsal unsur ile uyumsuzluk hafiftir. Tersi durumda toplam uyumsuzluk kayda değer büyüklükte olacaktır.

Ayrıca, kişinin karara bağlanmışlık düzeyi de uyumsuzluk boyutunu belirler. Kişi geri dönülemez olarak davranışa bağlı hissettiğinde uyumsuz tutum yeniden değerlendirme yolu ile "sonucun o kadar da kötü olmadığı" yönünde değiştirilirken, kişi iyi sonuç alamadığında kararla ilişkisini kesebileceğini ya da ona hiç uymayabileceğini düşünürse tutum değişikliğini gerektirecek bir bilişsel uyumsuzluk da yoktur (Freedman vd., 1993: 471-472).

Bilişsel uyumsuzluk için özgür bir seçimin varlığı gerekmektedir. Aksi halde kişi kendisini sorumlu hissetmeyecektir. Bilişsel uyumsuzluk yaşaması için kişinin kendisini sorumlu hissetmesi şarttır (Freedman vd., 1993: 476). Bu durumda psikolojik rahatsızlık artacaktır.

Karşılaşılan uyumsuzluk miktarı, davranışın dış baskısı ya da gerekçesinin büyüklüğüyle ters orantılıdır. Örneğin, bir otorite figürü tarafından kendi tutumuna aykırı davranmaya zorlanan bir kişi, tutumunun aksine davrandığında şefkatle zorlanan bir şahıstan daha az uyumsuzluğa maruz kalır. Dış baskı yüksekse, bireyler tutumlarını karşıt tutum davranışıyla daha tutarlı hale getirebilirler (Harmon-Jones, 2012: 543). Yeterli ve yetersiz gerekçe de biliş üzerine etkilidir. Yeterli gerekçe koşullarında, kişinin inançları ve tutumları değişmez çünkü hareketleri için iyi bir dış sebep vardır (Aronson ve Carlsmith, 1963: 584).

İki veya daha fazla alternatifin neredeyse eşit çekicilikte olduğu durumda uyumsuzluğun büyüklüğü ve bunun azaltılması için ortaya çıkan baskı, alternatifleri eşit arzulamaya yaklaştıkça daha da artar (Brehm, 1956: 384). Seçilmemiş alternatiflerin seçilen alternatife göre göreceli çekiciliği ne kadar büyükse, davranışla ilgili uyumsuzluk o oranda artacaktır (Festinger, 1957: 37). Ancak iki alternatifin çekiciliği benzer olmadığında, bir alternatif diğerinden açıkça üstündür. Bu durumda, seçilmemiş alternatifi reddetmek ya az bilişsel uyumsuzluğa karşılık gelecek ya da uyumsuzluk yaşanmayacaktır.

Bir diğer etkili faktör, alternatifler arasında bilişsel çakışma/örtüşme derecesidir. Çakışma/örtüşme, iki seçeneğin benzer özellikleri paylaştığı durumlarda söz konusudur. Festinger'e (1957: 42) göre ürün/hizmet özelliklerinden oluşan kümedeki elemanların birçoğu bir diğer alternatifin küme elemanları ile aynı ise örtüşme derecesi yüksektir. Bilişsel örtüşme yüksek derecede olduğunda verilen karar, diğer alternatifin temel özelliklerinden vazgeçmeye yol açmadığından az bilişsel uyumsuzluk oluşur. Benzer özellikleri nedeniyle iki ürün, bilişsel çakışmayı yüksek derecede paylaşan ürünlerdir. Bu nedenle, herhangi birisinin seçimi ya çok az bilişsel uyumsuzluk ile sonuçlanacak veya hiç bilişsel uyumsuzluk yaşanmayacaktır.

\subsection{Uyumsuzluğun Azaltılması}

M.Ö. VI. yy’da yaşadığı varsayılan Yunan masalcı Aesop, başının üstündeki bir asmadan sarkan üzüme ulaşmaya çalışan tilki hakkında bir hikâye anlatır (Anonim): "Açlık çeken bir tilki asmadaki üzümlere ulaşmaya çalıştı ancak her ne kadar tüm gücüyle sıçradıysa da beceremedi. Birkaç denemeden sonra tilki vazgeçip, 'zaten 
daha olgunlaşmamışsın ekşi üzüme ihtiyacım yok' dedi'”. Kültürümüzde bu durumu benzer şekilde anlatan ifade ise "kedi yetişemediği (veya uzanamadĭ̆l) ciğere pis (veya murdar) dermiş" ş̧eklinde kullanılmaktadır (TDK, 2017).

Teoriye göre insanlar tutum ve davranışlarının çatışma içinde olmasından hoşlanmazlar, uyumsuzluğun azalması için motivasyon artar ve uyumsuzluğun gücü uyumsuz inançların sayısından, her iki inancın (düşüncenin) öneminden ve yukarıda açıklanan diğer faktörlerden etkilenir (Festinger, 1957: 13; Freedman vd., 1993: 464).

Uyumsuzluğu azaltmak veya ortadan kaldırmak için yönlendirilen eylemler uyumsuzluk azaltma davranışlarıdır (Mosala, 2007: 34). Bireyin hangi yöntemi kullanacağını tahmin etmek zordur ve muhtemelen birden fazla veya belki de tüm yöntemleri farklı zamanlarda kullanır (Cummings ve Venkatesan, 1976: 304).

Festinger (1957: 6) uyumsuzluğun, azaltılmasına yönelik psikolojik çabayı motive ettiğini belirterek, bireyin bunu 2 şekilde yapabileceğini savunur:

(1) Davranış değiştirmek

(2) Uyumsuz bilgiyi yok sayarak veya uyumlu yeni bilişsel unsurlar ekleyerek tutum değiştirmek.

Uyumsuzluğun nasıl azaltılabileceğiyle ilgili bu yöntemleri literatürde sıkça tekrarlanan örneğini kullanarak inceler. Sigara içmenin sağlıksız olduğu gerçeğiyle karşılaşan kişi için bu bilgi, bilinciyle ve davranışıyla uyuşmaz. Bu uyumsuzluğu azaltmak için baskı olacağı hipotezi doğruysa, kişinin ne yapması beklenir?

Davranış Değişikliği: Bireyler bilişsel uyumsuzluk yaşadıklarında davranış(lar)ını uyumlu bilişleri doğrultusunda değiştirebilirler. Örneğin sigara içen kişi, bu alışkanlığının zararı ile ilgili bilgisine uyumlu olarak davranışını değiştirebilir yani sigara içmeyi bırakabilir. Bu durumda artık içmiyorsa, yaptığı şeyle ilgili bilişi, sigaranın sağlığı için kötü olduğu bilgisiyle uyuşacaktır.

Fakat davranışlarımızı değiştirmek her zaman kolay olmaz. Bu örnekte olduğu gibi zararlı bir alışkanlığı bırakmanın zorluğu ya da satın alma davranışının çoğunlukla geri dönülemez olması buna örnektir. Bu yüzden uyumsuzluğu azaltma çabaları genellikle tutum değiştirmek yönündedir.

Tutum Değişikliği: Kişi, sigara içmenin etkileri hakkındaki düşüncelerini (tutumunu) değiştirebilir. Bunu iki şekilde gerçekleştirir: Uyumsuz bilişleri yok sayarak, diğer bir ifadeyle bilişlerin birbiriyle ilişkisini inkâr ederek, sigaranın herhangi bir zararlı etkisinin bulunmadığına inanıp (örneğin sigara içmek tehlikeli değildir) sigara içmenin etkileri hakkındaki tutumunu değiştirebilir ya da zararlı yönlerin önemsiz hale geldiği, iyi etkilere işaret eden uyumlu (örneğin düzenli spor yaparak sigaranın zararlarından kurtulabilirim veya sigara gerginliğimi azaltıyor, konsantre olmamı ve girdiğim ortamlarda sosyalleşmemi sağlıyor) yeni bilgiler ekleyebilir. Bireyin kendisine sigara içmenin tehlikelerinin korunmasız cinsel ilişki tehlikelerine ya da uyuşturucu kullanmaya kıyasla hafif olduğunu veya trafikte ölüm olasılığının daha fazla olduğunu hatırlatması da buna örnektir (Wingfield, 2005: 3). Sonunda, sigara içen kişi sigaradan sağladığı yararların (gevşeme, konsantrasyon, sosyalleşme) çok önemli olduğu sonucuna varıp uyumlu bilişlerin önemini arttırarak uyumsuzluğunu azaltacaktır.

Kassarjian ve Cohen (1965) de sigara içen ve içmeyenlerin, sigara kullanımı ve akciğer kanseri arasındaki ilişkiye dair bir raporun inandırıcılığına yönelik tutumlarını inceledikleri araştırmalarında, sigara içen kişilerin sigara kullanımı ve akciğer kanseri arasındaki ilişkiyi inkâr ettiklerini ya da uyumlu yeni bilgiler eklediklerini ortaya koymuşlardır.

Freedman ve meslektaşları (1993: 468) tutum değişimini kişinin pahalı bir araba aldıktan sonra kararıyla ilgili bilişsel uyumsuzluk yaşaması halinde başvuracağı yolları örnekleyerek açıklar. Pahalı bir araba aldıktan sonra, uzun yolda rahat bir araba olmadığını öğrenen kişi uyumsuzluk yaşar çünkü seçilen arabanın bazı yönlerinin kötü olduğuna ilişkin bilgi, kişinin o arabayı seçmiş olması gerçeği ile uyumsuzdur. Dolayısıyla kişi, arabanın uzun yolda rahat olmadığını öğrendiğinde kullanımının kolay, ekonomik ve güzel görünümlü olduğunu düşünebilir. Arabanın uzun yolda rahatsız edici olmasının önemli olmadığına çünkü onu yalnızca evi ve işi arasındaki kısa mesafede kullandığına karar verebilir ya da kendisini arabanın uzun yolda gerçekten rahat olduğuna inandırabilir. $\mathrm{Bu}$ şekilde, seçilen alternatifin algılanan önemini artırmış, seçilmemiş alternatiflerin algılanan çekiciliğini azaltmış ya da uyumsuz bilişi inkâr etmiş olacaktır. Bu süreç Şekil 1'de gösterilmiştir. 


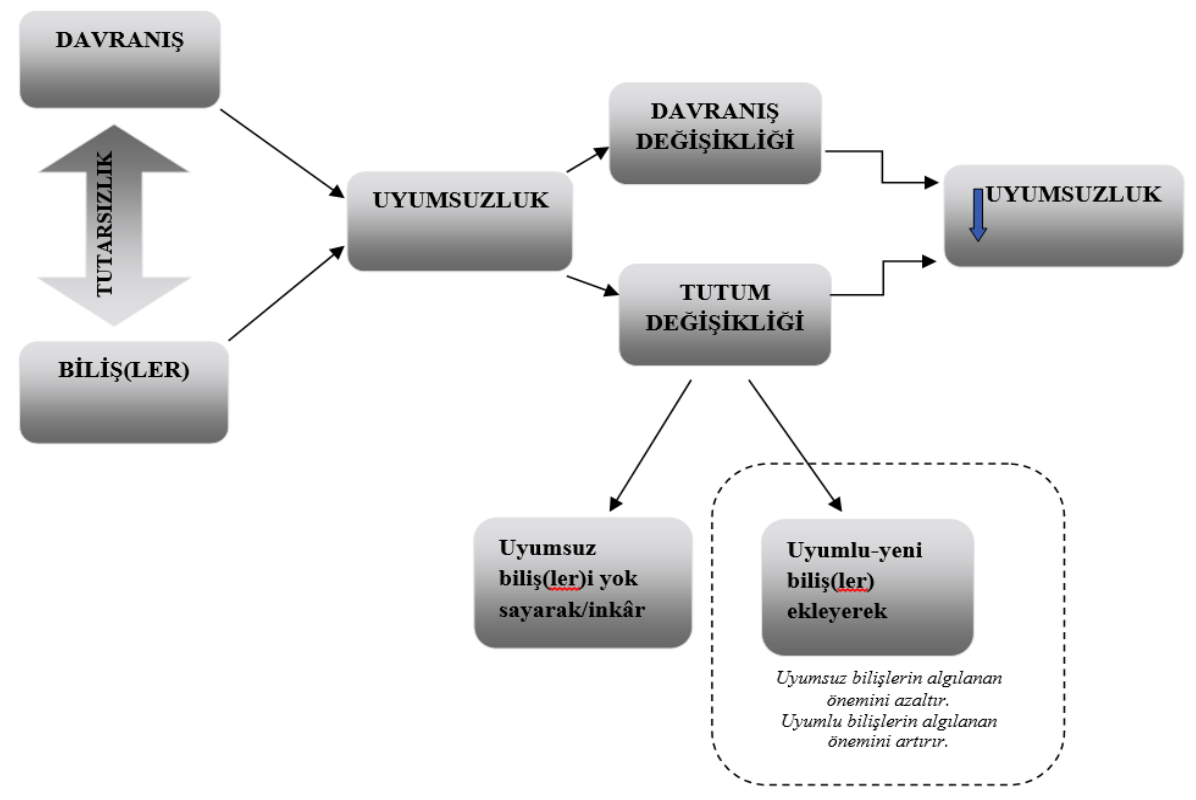

Şekil 1. Bilişsel Uyumsuzluk Süreci

Bununla beraber, ortak kararlarda kararın sorumluluğunu reddederek karar için karşı tarafı suçlamak (eşler, ortaklıklar) ve bireylerin, gerçekten rahatsız edici bilgilerin anılarını ve mevcut algılamalarını bloke ettiği seçici unutma da uyumsuzluk azaltma stratejileri arasında sayılabilir (Oliver, 1997: 255).

Birey, bu yollardan biriyle davranış ya da tutumunu değiştirmeyi başarabilirse yaptığı şey ve bildikleri arasındaki uyumsuzluğu azaltmış ya da ortadan kaldırmış olacaktır. Bununla birlikte bireyler tutarsızlıkları rasyonalize etmekte her zaman başarılı olamayabilirler.

\section{Satın Alma Süreçlerinde Bilişsel Uyumsuzluk}

Alternatiflerin cazibesinin farklılaşmasına yol açan bilişsel süreç, ancak kararın verilmesinden sonra ortaya çıkar (Festinger, 1957: 41). Peki, insanlar nasıl karar verirler? Görünüşte basit olan bu soru, onlarca yıldır psikologların ve asırlardır filozofların ilgisini çekmektedir. Karar vericiye karmaşık veya riskli durumlarda nasıl seçim yapacağı konusunda yön veren karar teorisinde amaç, bireye istediği her şeyi elde edebileceği başarılı seçimi yaptırmaktır. Temel husus, fayda ölçümüdür. Her alternatifin net çekiciliğinin doğru ölçümü yapılırsa, makul bir hassaslıkla kişinin en cazip alternatifi seçeceği öngörülebilir. Fakat her durumda seçim öngörüsü bu kadar kolay değildir. Yeterli ölçüme sahip olunmadığında ya da alternatifler karmaşıksa ve çeşitli yönlerin tek bir fayda ölçüsünde nasıl birleştirileceği bilinmediğinde karar teorisi için bir sorun var demektir. Hangi alternatifin seçileceğinin tahmini, karar verme konusundaki psikolojik sorunun küçük bir yönüdür (Festinger, 1964: 1).

Tüketicilerin satın alma kararlarını etkileyen pek çok faktörden söz etmek mümkündür. Aile, sosyal sınıf ve kültür gibi sosyo-kültürel faktörlerden söz edilebileceği gibi, motivasyon, algı, kişilik, tutum ve inançlar gibi psikolojik faktörler de satın alma süreçlerini etkiler. Medeni durum, gelir, eğitim, yaş, cinsiyet ve meslek gibi demografik özellikler de bireylerin satın alma kararlarını şekillendiren göz ardı edilemeyecek faktörlerdir. Burada önemli olan husus karar sonrası bilişsel sürecin karar öncesi bilişsel süreçten farklı olup olmadığını ortaya koymaktır ve bilişsel uyumsuzluk yaklaşımı karar öncesi ve sonrası süreci birbirinden ayırır.

Oliver (1997: 243), satın alma süreçlerinde bilişsel uyumsuzluğu tanımlamaktadır. Oliver'a göre uyumsuzluk, karar verme ve tüketimin ayrılmaz bir parçası ve geleceğin belirsizliklerinin neler getireceğinin merak uyandıran safhasıdır (1997: 261). Basit bir endişe olarak başlar ve karar döngüsünde daha sonraki satın alma aşamalarına tırmandırılır. Oliver, satın alma aşamalarını Alfa, Beta, Gamma ve Delta olarak dörde ayırmış ve bilişsel uyumsuzluk sürecini tanımlamıştır. Tablo 1 ve Şekil 2 satın alma sürecindeki aşamaları gösterir. 
Yücel, E., Çizel, B. / Journal of Yasar University, 2018, 13/50, 150-163

Tablo 1. Satın Alma Karar Aşamaları ve Belirsizlik Unsurları

\begin{tabular}{|c|c|c|c|}
\hline Aşama & Tanımı & Belirsizliğin Odă̆ & Psikolojik Yanıt \\
\hline Alfa & Karar öncesi & Alternatiflerin çekiciliği & Karar çatışması \\
\hline Beta & Karar sonrası, satın alma öncesi & $\begin{array}{c}\text { Vazgeçilen alternatiflere karşı } \\
\text { seçilmiş alternatifin çekiciliği }\end{array}$ & Endişe \\
\hline Gamma & $\begin{array}{c}\text { Satın alma sonrası, mülkiyet } \\
\text { (edinim) öncesi } \\
\text { Mülkiyet (edinim) sonrası, } \\
\text { kullanım/deneyim öncesi }\end{array}$ & $\begin{array}{c}\text { Vazgeçilen alternatiflerin } \\
\text { çekiciliği, seçilen alternatifin } \\
\text { performans yeterliliği }\end{array}$ & $\begin{array}{c}\text { Performans endişesi, } \\
\text { kendinden (karardan) } \\
\text { süphe }\end{array}$ \\
\hline Delta & Kullanım sonrası & $\begin{array}{c}\text { Performans sonuçları, gelecekteki } \\
\text { performans }\end{array}$ & $\begin{array}{c}\text { Pişmanlık, suçluluk, } \\
\text { memnuniyet/sizlik }\end{array}$ \\
\hline
\end{tabular}

Kaynak: Oliver, 1997

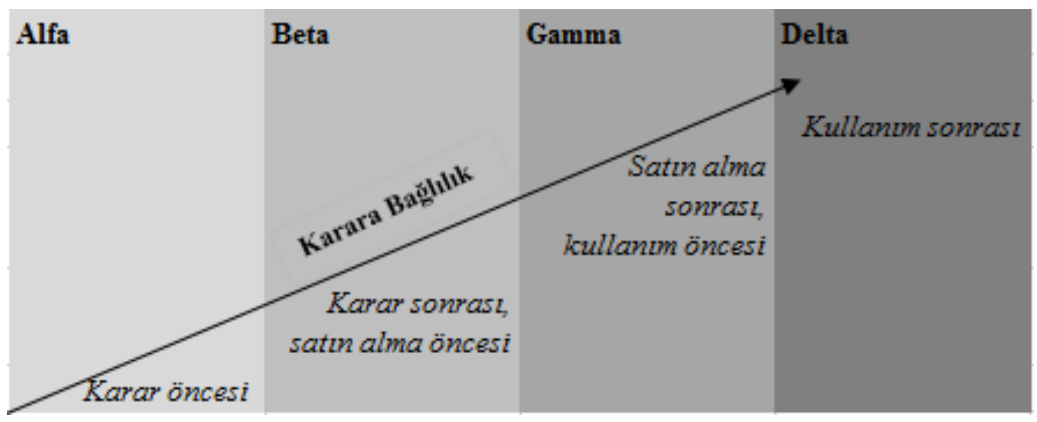

Şekil 2. Satın Alma Karar Aşamaları ve Karara Bağlılık

Kaynak: Oliver, 1997

Karar öncesi çatışmalara neden olan 'alfa' aşaması benzer alternatifler arasında zor bir seçimi gerektirir. Fakat hiçbir satın alma taahhüdü yapılmamıştır ve karar kolayca tersine çevrilebilir. Bu aşama sonraki aşamaları ortaya koymak için tanımlanır.

Karar verme öncesinde kişi, alternatifler ile ilgili bilgi toplarken ve değerlendirirken tarafsızdır yani bir alternatif lehine önyargılı değildir. Bu aşamada alternatiflerin çekiciliğinde değişiklikler olabileceği gibi, bunlar sistematik olmayacaktır (Festinger, 1964: 8). Satın alınması muhtemel ürünle ilgili bilgi, ürünle ilişkili var olan bilişsel elemanlara ek olarak ürün ve bunu kullanma kabulünün gelecekteki sonuçlarıyla ilgili bilişsel faktörlerle uyumlu olmalıdır (Festinger, 1957: 37). Çünkü karardan önce tutarsızlık ne kadar büyük olursa, sonrasında uyumsuzluk o kadar büyük olacaktır (Festinger, 1964: 2). Bu aşamada ürün ve bunu kullanma kabulünün gelecekteki sonuçlarıyla ilgili bilişsel faktörlerdeki belirsizlik, risk algısını beraberinde getirir. Algılanan risk, satın alma kararlarının sonuçlarını öngöremediğinde tüketicilerin karşılaştığı belirsizlik (Mosala, 2007: 30) ve satın alma davranışının sonucunda yaşanabilecek kayıplara dair nesnel beklenti (Akturan, 2007: 51) olarak tanımlanır. Algılanan risk bilişsel bir konudur ve bilişsel uyumsuzlukla kararın önemi, ürün bilgisinin eksikliği ve ürün veya hizmete aşinalık olmaması gibi bağlamsal faktörler bakımından bazı ortak noktalara sahiptir. Algılanan risk, bilişsel uyumsuzluğun bir öncüsüdür ve algılanan risk genellikle satın almadan önce görülürken bilişsel uyumsuzluk satın alma sonrası yapı olarak görülmektedir (Soutar ve Sweeney, 2003: 231). Karar öncesinde tüketicilerin risk algıları, satın alma sırasında karar vermenin çeşitli aşamalarını ve satış sonrası davranışları etkiler (Mitchell ve Boustani,1994: 62).

$\mathrm{Bu}$ aşamada farklı kaynaklardan bilgi arayışına girilmesi, kararı çevreleyen belirsizliğin yani algılanan riskin azaltılması çabasıdır (Akturan, 2007: 67). Böyle bir durumda bireyin karar sonrası uyumsuzluk öngörüsü varsa ya daha fazla bilgi arayacak ya da seçim için isteksizlik yaşayacaktır (Festinger, 1964: 151). Tüketiciler ne kadar çok risk algılarlarsa satın alma olasılıkları o kadar azalacaktır (Ayazlar, 2011: 25). Tüketiciler hata yapmaktan kaçınmakta ve satın alma ile elde edecekleri faydayı maksimize etmeye çalışmaktadırlar. Bu noktada algılanan risk tüketici davranışını açıklamada önemli bir rol oynamaktadır (Ayazlar, 2011: 25). Bununla beraber Mishra ve meslektaşları (2008: 11), ürünle ilgili bilgisi olmayan veya belirsiz bilgilere sahip olan tüketicilerin, ürüne ilişkin 
kesin bilgiye sahip olan tüketicilere kıyasla daha iyimser oldukları sonucuna vardıkları araştırmaları sonucunda bu durumu "mutluluk verici cehalet etkisi" (blissful ignorance effect) olarak adlandırmışlardır.

Tüketiciler algıladıkları risklere rağmen satın alma davranışı gerçekleştirmek zorunluluğu ile karşı karşıya kalmaktadırlar. Bu zorunluluk karşısında tüketiciler, başkalarının onayını alarak veya sürekli aynı markayı tercih ederek riski azaltmaya çalışırlar. Büyük markaları ya da özel testlerden geçmiş ürünleri tercih etmek, ücretsiz deneme olanaklarından faydalanmak, iade garantisi olan ya da en pahalı ürünü tercih etmek gibi stratejiler de kullanabilirler (Ateşoğlu ve Türker, 2013: 30; Roselius, 1971: 57-58).

Satın alma kararının hemen ardından ortaya çıkan "beta" aşamasında tüketiciler, ilk kez seçilmeyen alternatiflerin ortadan kalktığını düşündükleri için beklenen pişmanlıklarla başa çıkarlar. Beklenen bu pişmanlık durumu (gerçekleşenden farklıdır) tüketici üzerinde genel bir endişe hissi uyandırmaktadır. Başka bir ifadeyle diğer alternatifleri reddetme davranışı, seçilmemiş alternatifin çekiciliği ile birleşmiş uygun bilişsel elemanlar ve ret davranışı arasında uyumsuzluk yaratır (Oliver, 1997: 243). Satın alma öncesi aşamada yaşanan durum, beklenen pişmanlık açısından bilinmeyen sonuçlarla ilgili endişe (anksiyete) olarak açıklanır. Belirsizliğin ve beklenen kayıpların kapsamı algılanan risk seviyesini, risk algısı ise anksiyete seviyesini belirler. Belirsizlik yani algılanan risk artıkça anksiyete seviyesi de artmaktadır (Schaninger, 1976: 95; Dal ve Eroğlu, 2015: 379). Algılanan riskin hem anksiyeteyi hem de bilişsel uyumsuzluğu artırıyor olması, uyumsuzluğun ortaya çıkmasına yol açan aynı karar koşullarının aynı zamanda duygusal bir endişe hali ortaya çıkarabileceğini göstermektedir.

"Gama" aşaması, satın alma işlemini izler ancak ürün kullanımından önce gelir ve ürünün beklendiği gibi performans göstermeyeceği endişesi olarak tanımlanır. Mülkiyetin (ürün ya da hizmetin kişiye ulaşması) oluşup oluşmadığına bakılmaksızın satın alma ya da sahiplik artık gerçekleşmiştir. Birey, geçmişe dönük alternatiflerin gerçekten ortadan kalktığının, seçilen ürünün beklediği gibi çalışmayabileceğinin (ya da hizmetin beklediği gibi olmayabileceğinin) ve seçim hatası yapmış olabileceğinin farkına varır. Eski bir alternatifin olumlu yönleri ve alınan kararın olumsuz yönleri insan zihninde artan bir baskı oluşturur ve alıcının kararını gözden geçirmesini sağlar. Beta safhasında olduğu gibi gerçek performans henüz gözlemlenmemiştir. Bu aşamada uyumsuzluk en üst düzeye çıkmış ve memnuniyet oluşumunun öncesinde gerçekleşmiştir (Oliver, 1997: 243).

Tüketici karar alma ya da satın alma işleminden sonra "pişmanlık" duygusu yaşayabilir. Bu pişmanlığın nedeni karşıt bilişler/bilişsel unsurlardır (Bolia vd., 2016: 64). Pişmanlık, tüketicilerin davranışlarının ya da alımlarının daha iyi bir sonuca sahip olabileceğini fark ettiklerinde yaşanan olumsuz bilişsel duygudur (Zeelenberg ve Beattie, 1999: 76). Bilişsel uyumsuzluk bu yüzden "alıcı pişmanlığı" veya "karar sonrası pişmanlık" olarak da tanımlanabilir (Mosala, 2007: 19; Oliver, 1997: 250; Soutar ve Sweeney, 2003: 231).

İstenen bir kararı verdikten sonra bir tüketici, belirli bir markayı seçerek alternatif markayı seçmiş olması durumunda sahip olabileceği olumlu niteliklerden vazgeçtiğini hissedebilir. Satın alınan markanın tüketicilerin arzulanan beklentilerini karşılamaması durumunda suçluluk vurgulanabilir. Böyle bir senaryoda tüketici, bir hizmetle/ürünle ilgili olumlu özellikleri görmezden gelebilir ve bunların gereksiz olduğunu düşünebilir (Sharma, 2014: 836). Başlangıçta tüketicilerin yardım olmadan çeşitli uyumsuzluk azaltma stratejilerini kullanabilmelerine rağmen, uyumsuzluk sürecini anlayan yöneticiler özellikle de uygun bilgi sağlamak yoluyla tüketiciye yardımcı olabilirler (Oliver, 1997: 253). Pazarlamacıların satış sonrası iletişimi, tüketicilerin marka seçimleriyle ilgili iyi hissetmeleri ve olumsuz psikolojik durumu azaltabilmeleri için önemlidir (Kotler ve Armstrong, 2012: 174). Nitekim tüketicide ileride oluşması arzulanan tekrar seçim olasılığı bilişsel uyumsuzluk seviyesinden etkilenir, yeniden satın alma ve marka sadakati ile bilişsel uyumsuzluk olgusu bağlantılıdır (Mittelstaedt, 1969: 444).

Satın alma sonrasında tüketiciyle kurulan iletişim tüketicinin mağazaya karşı olumlu tutum geliştirmesine ve yeniden satın alma niyetinde artışa sebep olur (Hunt, 1970: 51). Tüketicilerin satın almadan sonra yaşadıkları uyumsuzluk, ürün iade isteklerinin önemli bir nedenidir ve satın alma sonrası iletişim ürün iade isteklerini azaltarak yeniden satın alma davranışında artışa yol açar (Milliman ve Decker, 1990: 167).

Bir ürünün kullanımını takip eden "delta" aşamasında ürün ya da hizmetin performansı bilinir. Tüketici, satın alımın sonucunu değerlendirir. Satın alma memnuniyeti, bir üründen beklenen veya beklenenden daha fazla fayda sağlamaktır. Nitekim LaBarbera ve Mazursky’a (1983: 393) göre alıcı memnuniyeti, alıcının ürün beklentileri ile algılanan performans arasındaki yakınlığın bir fonksiyonuyken Cadotte ve meslektaşları (1987: 306), alıcı memnuniyetini "ürün performansı ile buna tekabül eden normatif standart arasındaki yargisal farklılığa karşı duygusal tepki" olarak tanımlar. Bu aşamadaki pişmanlık artık memnuniyetsizliği ifade eder. Alıcılar, bir ürünün kullanımıyla ilgili deneyimleri beklentilerini aştığında tatmin olurlar ve olumlu deneyime sahip tüketici satın alınan markaya sadakat sağlayabilir. Müşteri ne kadar memnun olursa, markaya ve satıcıya sadık olma olasılığı da artar. Diğer bir ifadeyle, müşteri değeri ve memnuniyeti gelecekteki satın alma kararlarını etkiler (Mosala, 2007: 19). Deneyimlerin beklentilerin altında olduğu durumlarda ise müşteriler memnun değillerdir.

Satın alma öncesi evrede ortaya çıkan yapı, endişe olarak etiketlenir ve karar sürecinde artar. Aynı biliş ve duygularla karar verildikten sonra, önceki alternatiflerin ortadan kalkmasıyla gerçek uyumsuzluğa dönüşen yapı, kullanım ve tecrübe ile memnuniyet ya da memnuniyetsizliği doğurur (Oliver, 1997: 243; Sweeney vd., 2000: 374). Bu anlamda uyumsuzluk ve memnuniyetin kavramsallaştırılmasında paralellikler vardır. Bununla birlikte kavramlar arasında iki önemli fark vardır (Sweeney vd., 2000: 374). Birincisi, uyumsuzluk hemen karar 
sonrasında meydana gelir. Memnuniyet ise performans sonrası durum beklentilerle kıyaslandığından, kullanımdan sonra değerlendirilir. İkincisi, memnuniyet bilinen performansın ve beklentilerin kıyaslanmasına dayanır; uyumsuzluk bilinmeyen sonuçlarla ilgilidir (Oliver, 1997: 247; Sweeney vd., 2000: 374).

Tüketicinin kararı sonrası bilişsel uyumsuzluk yaşayıp yaşamaması durumu, ürün/hizmet sağlayıcıların nihai hedefi olan tüketici memnuniyetini ve yeniden satın alma davranışını yani marka sadakatini doğrudan etkilemektedir. Tüketici davranışlarının nedenlerini anlamaya çalışan pazarlama teorisyenleri tarafından benimsenen teorinin tüketici davranışı araştırmalarıyla kavramsal uyumu analiz edildiğinde ise, tüketicilerle ilgili farklı bilgi parçalarını birbirine bağlamak için kullanıldığı, reklamların algılanışı, hizmet kalitesi ve marka sadakatiyle arasındaki ilişkinin sorgulandığı ve elde edilen kanıtların hem teoriyi destekler hem de tekrar eder nitelikte olduğu görülmektedir. Literatür taraması sonuçlarının Tablo 2'de sunulduğu pazarlama alanında ise teori, çoğunlukla genelleştirilebilirliği arttırmaya hizmet etmiştir. 
Yücel, E., Çizel, B. / Journal of Yasar University, 2018, 13/50, 150-163

Tablo 2. Teoriyi Konu Alan Pazarlama Çalışmaları

\begin{tabular}{|c|c|c|c|c|}
\hline Yazar/lar & Alan & Amaç & $\begin{array}{l}\text { Kavramlar, Teori, } \\
\text { Yaklaşım, Model }\end{array}$ & Yöntem /Kapsam \\
\hline Kaish, 1967 & Pazarlama & $\begin{array}{c}\text { Pazarlamada kolayda, beğenmeli ve özellikli mallar } \\
\text { olarak sınıflandırılan ve satın alma davranışına konu } \\
\text { olan ürünleri bilişsel uyumsuzluk teorisiyle ele alıp, } \\
\text { ürün özelliklerinin uyumsuzluk yaratma potansiyellerini } \\
\text { tanımlamak. }\end{array}$ & Ürün sinıflandırma & Teorik Analiz \\
\hline George ve Edward 2009 & Pazarlama & $\begin{array}{l}\text { Satın alma tutumu ve bilişsel uyumsuzluk arasındaki } \\
\text { ilişkiyi incelemek. }\end{array}$ & Marka ilgilenimi & $\begin{array}{c}\text { Nicel: Regresyon } \\
\text { Pondicherry ve Goa Üniversitesinden } \\
\text { 500-600 potansiyel kat1lımciya e- } \\
\text { posta yoluyla anket uygulamas1. }\end{array}$ \\
\hline Korgaonkar ve Moschis, 1982 & Pazarlama & $\begin{array}{c}\text { Marka ilgilenimi ve bilişsel uyumsuzluk arasındaki } \\
\text { ilişkiyi incelemek. }\end{array}$ & Marka ilgilenimi & $\begin{array}{l}\text { Nicel: Anova } \\
75 \text { üniversite öğrencisine anket } \\
\text { uygulaması. }\end{array}$ \\
\hline George ve Yaoyuneyong, 2010 & Pazarlama & $\begin{array}{l}\text { Seyahat alışverişinde dürtüsel ve planlı alımlar ile } \\
\text { bilişsel uyumsuzluk arasındaki ilişkiyi incelemek. }\end{array}$ & Satın alma kararları & $\begin{array}{l}\text { Nicel: Regresyon } \\
\text { Alı̧veriş gezilerine çıkan üniversite } \\
\text { öğrencilerine anket uygulaması. }\end{array}$ \\
\hline Olsen, 2008 & Pazarlama & $\begin{array}{l}\text { Uyumsuzluk ve satın alma kararı arasındaki ilişkiyi } \\
\text { incelemek. }\end{array}$ & $\begin{array}{l}\text { Finansal satın alma } \\
\text { kararları }\end{array}$ & Teorik Analiz \\
\hline Bawa ve Kansal, 2008 & Pazarlama & $\begin{array}{l}\text { Hizmet özellikleri ve türlerinin bilisssel uyumsuzluk } \\
\text { olasılığını etkileyip etkilemediğini ortaya koymak. }\end{array}$ & $\begin{array}{l}\text { Hizmet özellikleri ve } \\
\text { türleri }\end{array}$ & Teorik Analiz \\
\hline
\end{tabular}


Yücel, E., Çizel, B. / Journal of Yasar University, 2018, 13/50, 150-163

\begin{tabular}{|c|c|c|c|c|}
\hline Kim, 2011 & Pazarlama & $\begin{array}{l}\text { Bilişsel uyumsuzluk ile güven, değer ve olumsuz } \\
\text { ağızdan ağıza iletişim arasındaki ilişkiyi incelemek. }\end{array}$ & $\begin{array}{l}\text { Ürün/hizmet sağlayıcıya } \\
\text { karşı tutum }\end{array}$ & $\begin{array}{c}\text { Nicel: Two-tailed tests. } \\
\text { Katılımcıların yakın geçmişte } \\
\text { kullandıkları otel/moteli mail yoluyla } \\
\text { değerlendirmeleri. }\end{array}$ \\
\hline Tanford ve Montgomery, 2015 & Pazarlama & $\begin{array}{c}\text { Seyahat sektöründe sosyal etki ve bilişsel uyumsuzluk } \\
\text { ilişkiyi incelemek. }\end{array}$ & Sosyal etki, azınlık etkisi & $\begin{array}{l}\text { Nicel: Analyses of covariance } \\
\text { Bir üniversitede otelcilik } \\
\text { programında } 308 \text { lisans öğrencisine } \\
\text { anket uygulaması. }\end{array}$ \\
\hline Veer ve Shankar, 2011 & Pazarlama & $\begin{array}{l}\text { Toplumsal değer, inanç ve beklentiler ile bilişsel } \\
\text { uyumsuzluk arasındaki ilişkinin tespiti. }\end{array}$ & Ürün/hizmet reklamları & $\begin{array}{c}\text { Nicel: Anova ve Mancova } \\
\text { İngiltere } 424 \text { dindar tüketiciye anket } \\
\text { uygulaması. }\end{array}$ \\
\hline Hunt, 1970 & Pazarlama & $\begin{array}{l}\text { Satıss sonrası iletişim ve bilişsel uyumsuzluğun } \\
\text { azaltılması arasındaki iliş̧inin tespiti. }\end{array}$ & Satış sonrası iletişim & 152 tüketiciyle görüsşme. \\
\hline Ayazlar, 2011 & Pazarlama & $\begin{array}{c}\text { Web sitesi kalitesi, risk ve güvenin bilişsel çelişki } \\
\text { üzerine etkileri }\end{array}$ & Web sitesi tasarımı & $\begin{array}{c}\text { Adnan Menderes Üniversitesi Bellis } \\
\text { Bay (Didim MYO Sosyal Tesisler) } \\
\text { müşterilerine online anket } \\
\text { uygulaması. }\end{array}$ \\
\hline
\end{tabular}



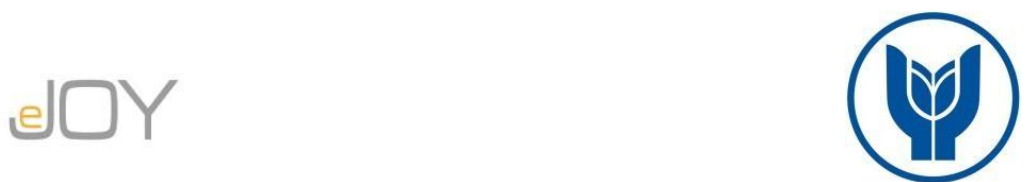

Yücel, E., Çizel, B. / Journal of Yasar University, 2018, 13/50, 150-163

Tüketici davranışı araştırmalarına bakıldığında en göze çarpan uygulama alanı, klasik satın alma sonrası uyumsuzluk yani tüketicilerin seçilen alternatifin olumsuz özellikleriyle karşı karşıya kalırken reddedilen alternatiflerin kaçırılan uygun özellikleriyle mücadele ettiği fenomenidir (Koller ve Salzberger, 2007: 218). Fakat teorinin pazarlama alanındaki araştırmalarının çok az olduğu dikkat çekmektedir. Bu durum, satın alma sonrası tüketiciye ulaşma zorluğundan kaynaklanıyor olabilir. Bilişsel uyumsuzluğun tespiti için karar sonrası geçen zaman önemlidir. Satın alma öncesinde kaygı olarak tanımlanan yapı kararın hemen sonrasında bilişsel uyumsuzluk, tüketim sonrasında ise memnuniyet ya da memnuniyetsizlik olarak etiketlenir. Bu durum ölçüm sıkıntısının yanında zamanlama sıkıntısını da beraberinde getirmektedir. Nitekim Cummings ve Venkatesan (1976: 307), tüketici davranışı bağlamında bilişsel uyumsuzlukla ilgili 23 çalışmayı gözden geçirmişler ve birtakım deneysel ve kavramsal sınırlamalar saptamışlardır. Araştırmacılara göre katılımcılara satın alma işlemi sonrasında yaşadıkları endişeyi sormak ve bu bilgiyi uyumsuzluk seviyesi ölçütü olarak kullanmak, sonuçların sağlamlığı konusunda şüphe yaratmaktadır. Çalışmaların çoğunda uyumsuzluk için gerekli olan tüm koşulların (karar gönüllü olmalı, kararın geri alınamayacağına dair taahhüt olmalı ve uyumsuzluk yaratacak kadar önemli olmalıdır) varlığı şüphelidir. Bununla birlikte genel değerlendirmelerinde, tüketici davranışı bağlamında bilişsel uyumsuzluğun varlığını destekleyen kanıtların, onlara karşı verilen kanıtlardan daha önemli olduğunu belirtmişlerdir.

\section{SONUC}

Bilişsel uyumsuzluk, tüketici davranışını anlamak için çeşitli yollar sunmaktadır. Organizasyonel satın alma durumunda değil kişisel satın alma durumunda ortaya çıkar. Alternatiflerin sayısı arttığında, alternatifler arasındaki farkın az olduğu ve marka ilgileniminin arttı̆ğ durumlarda bilişsel uyumsuzluk da artar (Bawa ve Kansal, 2008: 38). Kesinlikle tüm alım satım problemlerine tek çare değildir. Elbette ki tüm davranışları açıklamaz; kesin tahminlere izin vermez ve sosyal bilimciler tarafından eksiksiz bir cevap olarak sunulmamıştır. Bununla birlikte sektöre ve araştırmacılara insan davranışını anlamak için geniş bir referans çerçevesi sağlayabilir (Kassarjian ve Cohen, 1965: 63).

Bütün satın alma kararları uyumsuzluğa neden olmaz. Tüketiciler, önemsiz ya da önemsiz sonuçları olan kararlarda (örneğin günlük gazeteler) uyumsuzluk yaşamazlar (Oliver, 1997: 251). Satın alma durumlarında bilişsel uyumsuzluktan söz edebilmek için kararın önemli, geri alınamaz ve gönüllü olması gerekir (Cummings ve Venkatesan 1976: 304; Souter ve Sweeney, 2003: 229).

Uyumsuzluk yaşayan tüketici, alternatif bir ürünü/hizmeti seçmiş olsaydı sonucun daha iyi olup olmayacağını sorgulayan tüketici anlamına gelir. Bu durum kendisine sağlanan hizmeti ya da satın aldığı ürünü değerlendirirken diğer alternatiflerin olumlu özelliklerini göz önünde bulunduracağı anlamına gelir ki bu memnuniyetin oluşmasına olumsuz yönde etki edecektir. Bilişsel uyumsuzluk teorisi, uyumsuzluk yaşayan tüketicilerin satın alımlarının doğru olduğu yönünde ikna edilirlerse uyumsuzluğun azalacağını öngörür ve dolayısıyla tüketiciler hizmet/ürün kalitesini daha iyi algılayacaklardır (Keng ve Liao, 2013). Bilişsel uyumsuzluğun azaltılması, müşteri memnuniyetinin oluşması için gerekli ön koşuldur. Zaten teorinin temeli bireylerin beklentileri ile gerçekleşenler arasında uyumsuzluk yaşadıklarında, önceki beklentileri ile satın alma sonrası algıları arasındaki boşluğu azaltma çabalarına dayandığından müşteriler yaşadıkları uyumsuzluğu azaltma yönünde işletmecilere yardımcı olacaklardır. Örneğin, kendilerini aldıkları hizmet ya da ürünün pek de kötü olmadığı konusunda inandırma ya da işletmenin sorun çözme çabasını olduğundan daha olumlu algılama eğilimi gösterirler.

Markaların ve tüketicilerin giderek daha karmaşık hale geldiği pazarda, tüketicilerin güvenle alışveriş yapmalarını sağlayarak algılanan riski ve satın alma sonrası bilişsel uyumsuzluğu azaltmak işletmeler açısından hayati önem taşımaktadır. Benzer fiyat ve hizmete sahip işletmelerin kendilerinin tercih edilmesini sağlayacak yeni hizmet özellikleri geliştirmesi ve bu özellikleriyle diğerlerinden ayrışması, karmaşık ve rekabetçi pazarda ayakta kalabilmek için son derece önemlidir. Böylece tüketicinin yaptığı seçimle ilgili kendine güveni artacaktır. Çünkü tüketicinin yaptığı seçimi sorgulaması ve yanlış karar vermiş olabileceğiyle ilgili şüphe duyması olarak da tanımlanabilen bilişsel uyumsuzlukta bireyin kendine güveni çok önemlidir. Kendine ve kararlarına güvenen tüketiciler bilişsel uyumsuzluğu daha az deneyimlerler. Pek çok araştırma, yaptığı seçimle ilgili olarak tüketicinin kendine olan güvenini arttırmanın uyumsuzluğu azaltılabileceğini ortaya koymuştur. İşletmeler, kendi ürün ya da hizmetini tercih eden tüketicilere bu seçimlerini destekleyici bilgiler sunmalı, satı̧s sonrası iletişime önem vermelidirler. Sonuç memnuniyetsizlik olursa, tüketicinin işletme hakkında olumsuz konuşmasının yanında ileride yeniden satın alma davranışı olmayacak ve dolayısıyla marka sadakati oluşmayacaktır. Müşterinin yaşadığı uyumsuzluğu dışa vurması için iletişim yollarının açık olması ve bu sürecin çok iyi yönetilmesi gerekmektedir. 


\section{KAYNAKÇA}

Akturan, U. 2007. Satın alma Karar Sürecinde Markaya Yönelik Algllanan Riskin Algllanan Değer Üzerindeki Etkisi. Yayımlanmamış Doktora Tezi. İstanbul Üniversitesi Sosyal Bilimler Enstitüsü, İstanbul.

Aronson, E. 1997. "Back to the Future: Retrospective Review of Leon Festinger's: A Theory of Cognitive Dissonance". The American Journal of Psychology, 110(1): 127-137.

Aronson, E. ve Carlsmith, J. M. (1963). "Effect of The Severity of Threat on The Devaluation of Forbidden Behavior". Journal of Abnormal and Social Psychology, 66(6): 584-588.

Ateşoğlu, İ. ve Türker, A. 2013. "Türkiye'de Tatil Yapan Turistlerin Algıladıkları Risk Türleri". Journal of Travel and Hospitality Management, 10(3): 24-44.

Ayazlar, R. A. 2011. Elektronik Satın Almada Web Sitesi Özelliklerinin Bilişsel Çelişki Üzerine Etkisi. Yayımlanmamış Yüksek Lisans Tezi. Adnan Menderes Üniversitesi Sosyal Bilimler Enstitüsü, Aydin.

Bawa, A. ve Kansal P. 2008. "Cognitive Dissonance And The Marketing Of Services: Some Issues". Journal of Services Research, 8(2): 31-51.

Bolia, B., Jha, S. ve Jha, M. K. 2016. "Cognitive dissonance: a review of causes and marketing implications". Researchers World, 7(2): 63-76.

Brehm, J. W. 1956. "Postdecision changes in the desirability of alternatives". The Journal of Abnormal and Social Psychology, 52(3): 384-38.

Breker, T. 2009. The Theory of Cognitive Dissonance and its Application in Marketing: An Overview of Literature and Practical Experiences. VDM Verlag Dr. Müller

Brownstein, A. L. 2003. "Biased predecision processing". Psychological Bulletin, 129(4): 545-568.

Cadotte, E. R., Woodruff, R. B. ve Jenkins, R. L. 1987. "Expectations and norms in models of consumer satisfaction". Journal of Marketing Research, 24(3): 305-314.

Cummings, W. H. ve Venkatesan, M. 1976. "Cognitive Dissonance and Consumer Behavior: A Review of the Evidence". Journal of Marketing Research, 13(3): 303-308.

Dal, Ö. G. V. ve Eroğlu, A. H. 2015. "Farklı Kişilik Özelliklerine Sahip Bireylerin Risk Algılarının Tüketici Davranışı Açısından İncelenmesi: Üniversite Öğrencileri Üzerine Bir Araştırma". Süleyman Demirel Üniversitesi İktisadi ve İdari Bilimler Fakültesi Dergisi, 20(2): 361-385.

Ehrlich, D., Guttman, I., Schönbach, P. ve Mills, J. 1957. "Postdecision exposure to relevant information". The Journal of Abnormal and Social Psychology, 54(1): 98-102.

Engel, J. F. 1963. "Are automobile purchasers dissonant consumers?". The Journal of Marketing, 27(2): 55-58.

Festinger, L., Riecken, H. W. ve Schachter, S. 1956. When Prophecy Fails: A Social and Psychoanalytical Study of a Modern Group that Predicted the Destruction of the World. Harper \& Row, New York.

Festinger, L. 1957. A theory of cognitive dissonance, Evanston, IL: Row \& Peterson.

Festinger, L. 1964. Conflict. Decision, and Dissonance. Sears, R. R. (Ed); Festinger, L. (Ed); Lawrence, D. H. (Ed). Stanford Studies in Psychology III, Stanford University Press, California.

Freedman, J. L., Sears, D. O. ve Carlsmith, J. M. 1993. Social Psychology. (Çev. A. Dönmez), 3. Basım, İmge Yayınları, İstanbul.

George, B. P. ve Edward, M. 2009. "Cognitive dissonance and purchase involvement in the consumer behavior context". IUP Journal of Marketing Management, 8(3/4): 7-24.

George, B. P. ve Yaoyuneyong, G. 2010. "Impulse buying and cognitive dissonance: A study conducted among the spring break student shoppers". Young Consumers, 11(4): 291-306.

Harmon-Jones, E. 2012. "Cognitive Dissonance Theory". Encyclopedia of Human Behavior, 2. Basım, 1: $543-$ 549.

Harmon-Jones, E. ve Mills, J. 1999. "An introduction to cognitive dissonance theory and an overview of current perspectives on the theory". E. Harmon-Jones (Ed) ve J. Mills (Ed). Cognitive dissonance: Progress on a pivotal theory in social psychology, American Psychological Association, Washington, 3-21.

Hunt, S. D. 1970. "Post-transaction communications and dissonance reduction". The Journal of Marketing, 34(3): 46-51.

Kah, J. A. ve Lee, S. H. 2016. "A new approach to travel information sources and travel behaviour based on cognitive dissonance theory". Current Issues in Tourism, 19(4): 373-393.

Kaish, S. 1967. "Cognitive dissonance and the classification of consumer goods". The Journal of Marketing, 31(4): 28-31.

Kassarjian, H. H. ve Cohen, J. B. 1965. "Cognitive Dissonance and Consumer Behavior". California Management Review, 8(1): 55-64.

Keng, C. J. ve Liao, T. H. 2013. "Self-confidence, anxiety, and post-purchase dissonance: a panel study". Journal of Applied Social Psychology, 43(8): 1636-1647.

Kim, Y. S. 2011. "Application of the cognitive dissonance theory to the service industry". Services Marketing Quarterly, 32(2): 96-112.

Koller, M. ve Salzberger, T. 2007. "Cognitive Dissonance as a Relevant Construct Throughout The DecisionMaking and Consumption Process-An Empirical Investigation Related to a Package Tour". Journal of 
Customer Behaviour, 6(3): 217-227.

Koller, M. ve Salzberger, T. 2012. "Heterogeneous development of cognitive dissonance over time and its effect on satisfaction and loyalty". Journal of Customer Behaviour, 11(3): 261-280.

Korgaonkar, P. K. ve Moschis, G. P. 1982. "An experimental study of cognitive dissonance, product involvement, expectations, performance and consumer judgement of product performance". Journal of Advertising, 11(3): 32-44.

Kotler, P. ve Armstrong, G. 2012. Principles of marketing. 14. Basim, Pearson Int. Edt., New Jersey.

LaBarbera, P. A. ve Mazursky, D. 1983. "A longitudinal assessment of consumer satisfaction/dissatisfaction: The dynamic aspect of the cognitive process". Journal of Marketing Research, 20(4): 393-404.

Liang, Y. 2014. The effect of cognitive dissonance on the selection of post-decision online reviews: Congeniality bias and refutational perspectives. Yayımlanmamış Doktora Tezi. Michigan State University, USA.

Milliman, R. E. ve Decker, P. J. 1990. "The use of post-purchase communication to reduce dissonance and improve direct marketing effectiveness". The Journal of Business Communication, 27(2): 159-170.

Mishra, H., Shiv, B. ve Nayakankuppam, D. 2008. "The blissful ignorance effect: Pre-versus post-action effects on outcome expectancies arising from precise and vague information". Journal of Consumer Research, 35(4): 573-585.

Mitchell, V. W. ve Boustani, P. 1994. "A preliminary investigation into pre-and post-purchase risk perception and reduction". European Journal of Marketing, 28(1): 56-71.

Mittelstaedt, R. 1969. "A dissonance approach to repeat purchasing behavior". Journal of Marketing Research, 6(4): 444-446.

Mosala, P. R. 2007. Post Purchase Behaviour (Cognitive Dissonance) Amongst Students at a Selected Higher Education Institution. Yayımlanmamış Doktora Tezi. Durban University Of Technology, Durban.

Oliver R. L. 1997. Satisfaction: A behavioral perspective on the consumer. New York: McGraw-Hill.

Olsen, R. A. 2008. "Cognitive dissonance: the problem facing behavioral finance". Journal of Behavioral Finance, 9(1): 1-4.

Roselius, T. 1971. "Consumer rankings of risk reduction methods". The Journal of Marketing, 35(1): 56-61.

Schaninger, C. M. 1976. "Perceived risk and personality". Journal of Consumer Research, 3(2): 95-100.

Sharma, M. K. (2014). "The Impact on Consumer Buying Behaviour: Cognitive Dissonance". Global Journal of Finance and Management, 6(9): 833-840.

Soutar, G. N. ve Sweeney, J. C. 2003. "Are There Cognitive Dissonance Segments?". Australian Journal of Management, 28(3): 227-249.

Sweeney, J. C., Hausknecht, D. ve Soutar, G. N. 2000. "Cognitive Dissonance after Purchase: A Multidimensional Scale". Psychology \& Marketing, 17(5): 369-385.

Tanford, S. ve Montgomery, R. 2015. "The effects of social influence and cognitive dissonance on travel purchase decisions". Journal of Travel Research, 54(5): 596-610.

TDK, Türk Dil Kurumu. 2017. Büyük Türkçe Sözlük

Telci, E. E., Maden, C. ve Kantur, D. 2011. "The theory of cognitive dissonance: A marketing and management perspective". Procedia Social and Behavioral Sciences, 24: 378-386.

Wingfield, J. H. 2005. Goal Systemic Analysis of Cognitive Dissonance Phenomena. Yayımlanmamış Doktora Tezi. University of Maryland, USA.

Veer, E. ve Shankar, A. 2011. "Forgive me, Father, for I did not give full justification for my sins: How religious consumers justify the acquisition of material wealth". Journal of Marketing Management, 27(5-6): 547-560.

Zeelenberg, M. ve Beattie, J. 1997. "Consequences of regret aversion 2: Additional evidence for effects of feedback on decision making". Organizational Behavior and Human Decision Processes, 72(1): $63-$ 78 . 